\title{
Reorientasi Pengaturan Pendekatan Multidoor System Penegakan Hukum Tindak Pidana Lingkungan Hidup Pada Sistem Peradilan Pidana Indonesia
}

\author{
Hotnando Mexson Simalango ${ }^{1}{ }^{*}$ Tajudin, ${ }^{2}$ Imamulhadi $^{3}$ \\ ${ }^{1}$ Mahasiswa Magister Hukum Universitas Padjadjaran, Bandung \\ hotnando13001@mail.unpad.ac.id \\ ${ }^{2}$ Dosen Hukum Pidana Universitas Padjadjaran \\ tajudin@unpad.ac.id \\ ${ }^{3}$ Dosen Hukum Lingkungan Universitas Padjadjaran \\ imamulhadi@unpad.ac.id \\ * Correspondence Author
}

\begin{abstract}
Abstrak
Pendekatan multidoor system dalam penegakan hukum lingkungan hidup merupakan salah satu strategi untuk memberantas dan menimbulkan efek jera terhadap pelaku. Hal ini didasarkan dengan adanya modus kejahatan lingkungan yang beragam atau bervariasi bentuk dan macam perbuatannya. Dengan cara menggabungkan beberapa peraturan perundang-undangan atas perbuatan pelaku yang beragam, maka multidoor system, dapat mendorong bentuk kerjasama antar tiap instansi atau penyidik PPNS dan sebagainya, yang sesuai dengan perbuatan pelaku dan peraturan perundang-undangan. Pelaksanaan multidoor system sebenarnya dapat membentuk penegakan hukum yang terintegrasi secara multidoor dan bahkan terciptanya sistem peradilan pidana terpadu. Namun, perlu diketahui dan ditelusuri kekuatan mengikatnya dari suatu peraturan yang menghasilkan multidoor system ini. Metode penelitian yang digunakan ialah yuridis normatif dengan kajian bahan hukum primer, sekunder dan tersier. Serta, didukung dengan pendekatan sosiologis, historis dan studi komparatif. Hasil pembahasan pertama, Pendekatan multidoor system merupakan hasil dari kebijakan pemerintah nasional, yang tentunya kekuatan mengikat masih lebih baik dan kuat Undang-Undang. Kedua, perlu adanya peninjauan kembali atas wawasan pengaturan pendekatan multidoor system, dengan lebih jelas dan komprehensif, tidak hanya sebatas kebijakan dalam pelaksanaan Undang-Undang.
\end{abstract}

Kata Kunci : Lingkungan Hidup, Multidoor System, Reorientasi, Sistem Peradilan Pidana

Naskah dikirim: 29 Desember 2020|Direvisi: 19 Februari 2021|Diterbitkan: 28 Februari 2021 


\begin{abstract}
The multidoor system approach in environmental law enforcement is a strategy to eradicate and create a deterrent effect on perpetrators. This is based on the existence of various environmental crime modes or various forms and types of actions. By combining several laws and regulations on the actions of various actors, the multidoor system can encourage forms of cooperation between each agency or PPNS investigators and others, in accordance with the actions of the perpetrators and the laws and regulations. The implementation of this multidoor system can actually form a multidoor integrated law enforcement and even the creation of an integrated criminal justice system. However, it is necessary to know and trace the binding strength of a regulation that produces this multidoor system. The research method used is juridical normative with a study of primary, secondary and tertiary legal materials. And, supported by sociological approaches, historical and comparative studies. The results of the first discussion, the multidoor system approach is the result of national government policies, of course, the binding force is still better and stronger by the law. Second, there needs to be a review of the insight into setting a multidoor system approach, more clearly and comprehensively, not only limited to policies in the implementation of the Law.
\end{abstract}

Keywords: Criminal Justice System; Environmental; Multidoor System; Reorientation;

\title{
Pendahuluan
}

Pendekatan multi-rezim hukum atau multidoor system merupakan strategi penegakan hukum yang dianggap (diharapkan) ampuh dalam memberantas tindak pidana kebakaran hutan dan lahan (karhutla), tindak pidana perikanan dan tindak pidana Minerba ${ }^{1}$. Dengan adanya pendekatan multidoor, diharapkan juga dapat meminimalisir peluang lolos nya pelaku kejahatan hingga kepada beneficial owner sebagai mastermind dalam beberapa tindak pidana tersebut. Bahkan strategi pendekatan multidoor system, diperuntukkan untuk pengenaan pertanggungjawaban pidana korporasi. Sanksi Pidana terhadap korporasi. (Lihat Pasal 116 Undang-Undang Nomor 32 Tahun 2009 tentang Perlindungan dan Pengelolaan Lingkungan Hidup dan adanya Peraturan Mahkamah Agung Nomor 13 Tahun 2016 tentang Tata Cara Penanganan Tindak Pidana Oleh Korporasi).

Selaras dengan hal diatas, bahwa dalam perkembangannya modus kejahatan saat ini telah beragam, sehingga peraturannya pun tidak hanya menerapkan satu undang-undang, tetapi dengan menggabungkannya pada beberapa undang-undang yang terkait atau bersinggungan satu sama

\footnotetext{
${ }^{1}$ Zamzam, "Kabandiklat Kejaksaan: Multidoor System Strategi Ampuh Berantas Karhutla Dan Pidana Minerba," Harian Terbit, last modified 2019, accessed February 26, 2021, https://harianterbit.com/read/110488/Kabandiklat-Kejaksaan-Multidoor-System-Strategi-Ampuh-BerantasKarhutla-dan-Pidana-Minerba.
} 
lain. Tentunya akan berdampak pada batas kewenangan atau peranan penegak hukum yang diatur oleh tiap-tiap peraturan yang dilanggar. Hal ini akan menjadi sulit untuk dipecahkan atau dilaksanakan dalam praktik penegakan hukumnya. Misalnya; apabila pelaku melakukan banyak perbuatan dan terjerat banyak Undang-Undang yang akan memberikan kewenangan secara masing-masing pada penyidik PPNS-nya.

Hubungan kewenangan penyidik PPNS dengan Polri, serta bahkan sesama Penyidik PPNS yang berbeda kewenangan antar tiap Undang-Undang yang ada, akan menarik untuk dibahas. Terlebih lagi bahwa dalam Sistem Peradilan Pidana Indonesia dari Sub-Sistem Penyidikan saat ini, akan selalu berpedoman pada Pasal 6 Kitab Undang-Undang Hukum Acara Pidana (KUHAP), bahwa penyidik bukan hanya Polisi Negara Republik Indonesia, melainkan adanya pejabat Pegawai Negeri Sipil sesuai dengan Undang-Undang yang memberi kewenangan secara khusus (Lebih lanjut lihat Pasal 7 sampai dengan 9 KUHAP).

Sekalipun benar bahwa masing-masing Undang-Undang secara khusus telah tersedia dan mengatur tindak pidana yang dilakukan beserta peranan tugas dan kewajiban penegak hukumnya secara khusus, namun dalam praktiknya bahwa terkait upaya penegakan hukum (baik tindak pidana lingkungan hidup maupun tindak pidana lainnya) yang dilakukan (ditegakkan) dari masing-masing penegak hukum mempunyai batasan kewenangannya satu sama lain tergantung dari indikasi perbuatan yang dilakukan oleh pelaku, Penegakan hukum adalah sebuah upaya yang dilakukan oleh pemerintah dengan menggerakan sistem penegakan hukum. ${ }^{2}$ Adapun UndangUndang yang dimaksud ialah Undang-Undang Nomor 18 Tahun 2013 tentang Pencegahan dan Perusakan Hutan, Undang-Undang Nomor 39 Tahun 2014 tentang Perkebunan, Undang-Undang Nomor 37 Tahun 2014 tentang Konservasi Tanah dan Air, Undang-Undang Nomor 32 Tahun 2014 tentang Kelautan, Undang-Undang Nomor 18 Tahun 2008 tentang Sampah, UndangUndang Nomor 18 Tahun 2008 tentang Sampah, Undang-Undang Nomor 5 Tahun 1990 tentang Konservasi Sumber Daya Alam Hayati dan ekosistemnnya, Undang-Undang Nomor 31 Tahun 2004 tentang Perikanan, Undang-Undang Nomor 41 Tahun 1999 tentang kehutanan, UndangUndang Nomor 26 Tahun 2007 tentang Penataan Ruang.

\footnotetext{
2 Anakotta, M. (2019). Kebijakan Sistem Penegakan Hukum Terhadap Penanggulangan Tindak Pidana Terorisme Melalui Pendekatan Integral. JURNAL BELO,5(1), 46-66. DOI : https://doi.org/10.30598/belovol5issue1page46-66
} 
Sekilas berbicara tipologi kejahatan lingkungan hidup dan kehutanan, bahwa terdapat beberapa bagian yaitu Perambahan kawasan hutan, pembakaran hutan dan lahan, pembalakan liar, kejahatan atas Perlindungan Satwa (hidupan liar) atau, Perusakan Lingkungan, Limbah B3/Sampah/B3 dan Pencemaran Industri. ${ }^{3}$ Bahkan beberapa tahun ini, telah terjadi isu lintas sektor dan saling berkaitan dengan kejahatan lainnya, oleh karenanya diperlukan kerja sama antar lembaga penegak hukum. Adapun Tindak Pidana atau kejahatan lintas sektor yang diikuti oleh pencucian uang, suap, korupsi, gratifikasi, dan penghindaran pajak. ${ }^{4}$

Secara Umum ketentuan tindak pidana Lingkungan Hidup yang diatur dalam UU Nomor 32 Tahun 2009 tentang Perlindungan dan Pengelolaan Lingkungan Hidup, telah terbagi menjadi dua bagian yakni delik materiil (Administrative Independent Crimes) dan delik formil (Administrative Dependent Crime). Adapun delik materiil dapat dilihat dalam pasal 98 ayat (2), (3), Pasal 99 ayat (2), (4), dan Pasal 108, yang pada intinya jenis perbuatan pidana atau perbuatan melawan hukum yang menyebabkan pencemaran atau kerusakan lingkungan hidup yang tidak perlu membuktikan pelanggaran berupa aturan-aturan hukum administrasi seperti izin. Sedangkan delik formil adalah perbuatan pidana atau perbuatan melanggar hukum yang bergantung harus adanya perbuatan melanggar hukum aturan administrasi. Hal ini dapat dilihat dalam pasal 98 ayat (1), Pasal 100, Pasal 101, 102, sampai dengan Pasal 115.

Mencermati keberagaman atau modus kejahatan baru tersebut, tentunya hal ini tidak menjadi hal yang baru apabila bidang kejahatan atau tindak pidana (Pemaknaan istilah "kejahatan" lebih menekankan pada arah kriminologi, sedangkan "tindak pidana" lebih kepada arah hukum pidana) tersebut dipisahkan secara nyata, karena perihal masing-masing tindak pidana telah diatur dengan baik secara hukum nasional di Indonesia. Tentunya akan dipertegas atau dibatasi berdasarkan penerapan asas legalitas. Sepenggal penjelasan bahwa asas legalitas bermula dari Code Penal Perancis, yang kemudian asas tersebut dimasukkan dalam Pasal 1 ayat (1) Wetboek van Straftrecht di Negeri Belanda yang tegas menyatakan, "Geen feit is strafbaar dan uit kracht van eene daaraan voorafgegane wettelijke strafbepaling' Kemudian dalam KUHP

${ }^{3}$ Sekretariat Direktorat Jenderal Penegakan Hukum Lingkungan Hidup dan Kehutanan, Rencana Kerja 2019 Direktorat Jenderal Penegakan Hukum Lingkungan Hidup Dan Kehutanan Diterbitkan Oleh Sekretariat Direktorat Jenderal Penegakan Hukum Lingkungan Hidup Dan Kehutanan (Jakarta, 2019), http://gakkum.menlhk.go.id/assets/info-publik/RENJA_GAKKUM_2019_4PRINT_A5_21.pdf.

${ }^{4}$ Hani Afrinita Murti, "Penguatan Kebijakan Penegakan Hukum Multidoor Sebagai Deterent Effect Untuk Menekan Laju Kasus Korupsi (Studi Kasus; Penerapan Pendekatan Multidoor Di Kementerian Lingkungan Hidup Dan Kehutanan)," in Reconstructing Public Administration Reform To Build World Class Government, 2017, 434445 . 
Pasal 1 ayat (1), bahwa "Tidak seorang pun dapat dipidana, kecuali berdasarkan kekuatan ketentuan perundang-undangan pidana yang telah ada pada saat perbuatan dilakukan.

Keberagaman perbuatan pidana yang dilakukan oleh si pelaku, tidak diatur secara khusus dalam Undang-Undang yang ada, karena Undang-Undang hanya mengatur satu tipologi kejahatan (tindak pidana). Sebut saja perbedaan Undang-Undang Perlindungan dan Pengelolaan Lingkungan Hidup dengan Perkebunan, Kehutanan, Suap, Korupsi dan lain sebagainya. Namun apabila dicermati dalam sisi lain secara umum, bahwa telah diakomodir dalam Kitab UndangUndang Hukum Pidana (KUHP) pada Pasal 63 sampai dengan Pasal 72. Hal ini sering disebut dengan peristilahan perbarengan tindak pidana (Samenloop van Strafbare Feiten). Sehingga dapat disimpulkan bahwa awal mula atau dasar akan adanya pendekatan multidoor system tentunya berlandaskan pada asas legalitas dan perbarengan tindak pidana.

Dengan adanya pendekatan tersebut, tentunya akan mendorong para aparat penegak hukum untuk melakukan penerapan beberapa peraturan terhadap indikasi perbuatan pelaku. Bahkan hal ini akan berdampak pada hubungan kinerja antar sub-sistem pada peradilan pidana yang sesuai dengan Integrated Criminal Justice System. Lebih lanjut, dicermati dalam UU Perlindungan dan Pengelolaan Lingkungan Hidup dan Undang-Undang lainnya, terkait keberadaan multidoor system merupakan sebagai suatu strategi atau pendekatan penegakan hukum lingkungan hidup, maka hal ini akan menjadi sangat menarik untuk dibahas dan dikaji secara komprehensif. Bagian yang menariknya ialah suatu pendekatan multidoor system yang menggabungkan beberapa Undang-Undang untuk menjerat pelaku atas beberapa perbuatannya, yang notabene bahwa dalam Undang-Undang secara khususnya mempunyai kewenangan dan tugas dari penegak hukumnya berbeda instansi, ini merupakan berasal dari suatu kebijakan. Sedikit banyak akan menimbulkan masalah dalam upaya penegakan hukum secara praktik lapangan-nya, karena akan berhubungan dengan asas lex specialis derogate legi generali (hukum khusus menyampingkan hukum umum) dan lex superior derogate legi inferiori (hukum yang tinggi mengesampingkan hukum yang rendah).

Penelitian ini menggunakan metode pendekatan yuridis normatif. Penelitian hukum normatif adalah penelitian hukum kepustakaan. ${ }^{5}$ Penelitian hukum normatif, dilakukan dengan cara meneliti bahan pustaka yang menjadi dasar dalam penelitian (ilmu) digolongkan sebagai

5 Soerjono Soekanto dan Sri Mamudji, (2001), Penelitian Hukum Normatif-Suatu Tinjauan Singkat.Jakarta: PT Raja Grafindo, Persada. 
data sekunder. Pendekatan yuridis normatif yang dilakukan didukung dengan pendekatan sosiologis, historis, dan studi komparatif. Penyampaian permasalahan yang digunakan adalah deskriptif analisis, yaitu spesifikasi yang melukiskan fakta-fakta dari data yang diperoleh berdasarkan kenyataan. Fakta tersebut kemudian dikaitkan dengan hukum yang berlaku, dibahas, dianalisis, dan ditarik kesimpulan yang pada akhirnya digunakan untuk menjawab permasalahan yang ada. ${ }^{6}$

Dengan adanya tulisan ini diharapkan dapat memperoleh gambaran mengenai konsep, pengaturan dan penerapan Multidoor system dalam Sistem Peradilan Pidana Terpadu di Indonesia. Penelitian yang bersifat deskriptif analisis, dimaksudkan untuk memberikan data yang diteliti tentang manusia, keadaan, atau gejala-gejala tertentu. Maksudnya, untuk mempertegas hipotesa, agar dapat memperkuat teori-teori lama atau di dalam kerangka menyusun teori-teori baru. ${ }^{7}$ Seperti penelitian hukum normatif pada umumnya, bahwa penelitian ini dianalisis secara kualitatif $^{8}$, yaitu analisis data yang diperoleh kemudian disusun dalam bentuk uraian-uraian berdasarkan asas-asas dan norma-norma hukum untuk mencapai kejelasan masalah yang dibahas dengan tidak menggunakan rumus. Penelitian dilakukan dengan mempelajari berbagai dokumen, literatur, peraturan perundang undangan yang kemudian dianalisis guna mendapatkan gambaran yang jelas berkaitan dengan identifikasi masalah yang diteliti.

\section{Pembahasan}

\section{Pengaturan Multidoor System terhadap Tindak Pidana Lingkungan Hidup dalam Hukum Positif Indonesia}

Salah satu instrumen penting dalam UU PPLH adalah Kajian Lingkungan Hidup Strategis (KLHS). Namun KLHS selama ini belum terlihat, sehingga pemerintah mengambil kebijakan dengan mempertimbangkan KLHS sebagai penjaga lingkungan hidup dalam kerangka pembangunan berkelanjutan. Selain itu, perlu pembenahan koordinasi dan harmonisasi lintas sektoral dalam penguatan perizinan dan instrumen lingkungan hidup. Ida Nurlinda memberikan catatan tersendiri atas permasalahan "state capture", yaitu dalam hal

\footnotetext{
${ }^{6}$ Amirudin and Zainal J, (2005), Pengantar Metode Penelitian Hukum. Jakarta: Raja Grafindo Persada.

${ }^{7}$ Soerjono Soekanto, (1986), Pengantar Penelitian Hukum. Jakarta: Penerbit Universitas Indonesia.

${ }^{8}$ E. Saefullah Wiradipradja, (2015), Penuntun Praktis Metode Penelitian Hukum Dan Penulisan Karya Ilmiah Hukum. Bandung: Keni Media.
} 
negara tersandera oleh ketelanjuran yang ada lama kerusakan dan pencemaran lingkungan hidup, butuh keberanian dan komitmen pemerintah dalam mengambil tindakan tegas terhadap para perusak dan pencemar lingkungan hidup. Terakhir, UU PPLH masih menyisakan banyak pekerjaan rumah untuk operasionalisasi-nya, dimana banyak pengaturan dalam UndangUndang ini belum dijalankan dengan baik, karena belum ada peraturan pelaksana, tersandera oleh peraturan sektoral serta kapasitas SDM untuk penerapan di lapangan. ${ }^{9}$

Pernyataan diatas, merupakan salah satu catatan keras atau bentuk teguran terhadap pemerintah dalam mengambil keputusan atas kebijakan yang telah dikeluarkannya. Bahkan sebelum dari itu, tak sedikit kritikan dan masukan yang diberikan terhadap pemerintah untuk menyikapi pemberantasan modus kejahatan lingkungan yang semakin marak dan kompleks. Guna menjawab tantangan Penegakan Hukum Lingkungan Hidup tersebut, maka Direktorat Jenderal Penegakan Hukum Lingkungan Hidup dan Kehutanan menggunakan 4 (empat) pendekatan penegakan hukum lingkungan hidup dan kehutanan, yaitu; kebijakan peningkatan kapasitas penegak hukum, kebijakan hukum multi instrumen, kebijakan multidoor (multi rejim hukum) dan kebijakan simbolik.

Sekilas berbicara kebijakan multi instrumen, jelas bahwa dalam Undang-Undang Perlindungan dan Pengelolaan Lingkungan Hidup dan Undang-Undang Kehutanan telah mengatur akan adanya instrumen penegakan hukum baik secara administratif, perdata dan pidana. Jelas sebagaimana dipaparkan sebelumnya bahwa terdapat delik materiil dan delik formil, yang telah menempatkan hukum pidana baik dapat digunakan pada bagian akhir atau dapat diterapkan sebagai awal. Penggunaan hukum pidana secara Ultimum Remidium atau last resort diterapkan terhadap pencemaran atau perusakan lingkungan yang bersifat tingkat kesalahan pelaku relatif tidak berat, dan/atau akibat perbuatannya tingkat kesalahan pelaku tidak berat, dan atau akibat perbuatannya relatif tidak besar, dan atau tidak menimbulkan keresahan masyarakat. Sedangkan, Penggunaan hukum pidana secara Primumum Remidium berbanding terbalik dengan Ultimum Remidium, yaitu tingkat kesalahan pelaku relatif lebih berat dan/atau perbuatannya relatif besar, dan/atau perbuatannya menimbulkan keresahan bagi masyarakat.

9 Kormen Barus, "Penegakan Hukum Lingkungan Di Indonesia Masih Lemah," Industry.Co.Id, last modified 2019, accessed February 24, 2021, https://www.industry.co.id/read/54751/penegakkan-hukumlingkungan-di-indonesia-masih-lemah. 
Hal ini dipertegas dengan adanya pernyataan dari Dirjen Penegakan Hukum Lingkungan Hidup dan Kehutanan (KLHK), bahwa dalam Rencana Strategik Penegakan Hukum Lingkungan Hidup dan Kehutanan (2015-2019), terdapat tantangan penegakan hukum yang dihadapi oleh KLHK dengan meningkatnya kasus-kasus lingkungan hidup dan kehutanan meliputi eksternal dan internal. Adapun tantangan yang harus dihadapi ialah terjadi perluasan kewenangan, peningkatan sumber daya, yang berimbas pada perubahan cara kerja yang harus dikoordinasikan. Sedangkan, dari luar, peranan KLHK dalam penegakan hukum sangat diharapkan masyarakat akan keadilan dapat diperoleh. ${ }^{10}$

Berbicara Multidoor system, merupakan suatu pendekatan penegakan hukum atas rangkaian atau gabungan tindak pidana yang mengandalkan dan menerapkan berbagai peraturan perundang-undangan. Hal ini merupakan bentuk kerjasama antar penegak hukum dalam mengatasi kejahatan dengan menggunakan dasar pendekatan berbagai peraturan yang ada. Adapun tujuannya ialah untuk meminimalkan kemungkinan pelaku melarikan diri dari sanksi pidana yang lebih berat, serta memberikan efek jera dan memaksimalkan pengembalian kerugian negara akibat suatu perbuatan (kejahatan).

Perwakilan Mahkamah Agung, M Saleh, menyatakan pendekatan “multidoor" yang akan diadopsi MA ialah salah satu strategi mendorong para hakim menerapkan berbagai per Pendekatan "Multidoor", tentunya memiliki harapan besar terhadap penegak hukum untuk menangani modus kasus kejahatan hijau (green crime) yang berkembang dan tentunya dapat menjadi jawaban atas "dominasi-peranan" di antara aparat penegak hukum yang bersifat pengkotakan. ${ }^{11}$ Bahkan dapat menjadi solusi untuk menggabungkan rangkaian beberapa perbuatan pidana yang berbeda dilakukan oleh seorang tersangka maupun terdakwa. Bahkan dapat menjadi jawaban atas keterbatasan penegak hukum pidana dalam sistem peradilan pidana, yang mana apabila dilakukan pendekatan "multidoor" diantara penegak hukum dalam menangani kasus yang sulit maka satu sama lain dapat membantu dan menutupi kekurangankekurangannya. Hal ini dikarenakan bahwa kejahatan lingkungan saat ini merupakan salah

\footnotetext{
${ }^{10}$ Hani Afrinita Murti, "Penguatan Kebijakan Penegakan Hukum Multidoor Sebagai Deterent Effect Untuk Menekan Laju Kasus Korupsi (Studi Kasus; Penerapan Pendekatan Multidoor Di Kementerian Lingkungan Hidup Dan Kehutanan), Op.Cit."

${ }^{11}$ Yesmil Anwar and Adang, Sistem Peradilan Pidana, Konsep, Komponen Dan Pelaksanaannya Dalam Penegakan Hukum Di Indonesia (Widja Padjajaran, 2009).
}

DOI: https://doi.org/10.30598/belovol6issue2page232-255 
satu masalah antar (nasional) yang berkembang sangat cepat dan luas, sehingga sulit untuk ditangani dalam upaya penegakan hukumnya.

Konsep akan hadirnya pendekatan "multidoor" dalam tindak pidana lingkungan hidup, bermula dengan adanya Nota Kesepahaman atau MoU antara Menteri Kehutanan, Menteri Keuangan, Jaksa Agung, Kepala kepolisian dan Kepala Pusan Pelaporan dab Analisis Transaksi Keuangan RI tentang peningkatan kerja sama penegakan hukum untuk pengelolaan sumber daya alam yang berkelanjutan dalam rangka REDD+ pada tanggal 20 Desember 2012 dan ditindaklanjuti dengan MoU di tingkat eselon 1 pada tanggal 20 Mei $2013^{12}$. Lebih lanjut Keputusan Direktur Jenderal RI Nomor PHLHK SK.5 / PHLHK-Setdit / 2015 tentang Pembentukan Tim untuk Pembentukan Peraturan Presiden tentang Pedoman Penegakan Hukum Terpadu dalam Perlindungan Lingkungan dan Manajemen, dan Keputusan Direktur Jenderal PHLHK Nomor SK.6 / PHLHK-PHP / 2015 tentang Tugas Kekuatan untuk Investigasi Lingkungan dan Kejahatan Kehutanan ${ }^{13}$. Selain itu, pendekatan ini diatur dalam Peraturan Jaksa Agung Republik Indonesia Nomor PER-029/A/JA/2014 tentang Organisasi dan Tata Kerja Satuan Tugas Sumber Daya Alam Lintas Negara.

Mengamati dan mencermati dasar hukumnya Multidoor system, bahwa hadirnya multidoor berlandaskan pada kewenangan penanganan penegakan hukum terkait kejahatan atau pelanggaran lingkungan hidup, yang telah diatur dalam Pasal 63 ayat (1) huruf a UndangUndang Nomor 32 Tahun 2009 tentang Perlindungan dan Pengelolaan Lingkungan Hidup, yaitu "Pemerintah bertugas dan berwenang menetapkan kebijakan Nasional. Dengan demikian bahwa pendekatan Multidoor sebagai hasil dari kebijakan pemerintah nasional untuk menyikapi perbaikan penegakan hukum lingkungan. Sekilas bahwa pendekatan multidoor system, yang diterapkan, belum mempunyai mekanisme yang pasti, lemahnya kelembagaan, belum adanya standar operasional prosedur maupun pedoman yang mengatur mekanisme dalam pelaksanaan penyidikan dengan pendekatan multidoor belum direalisasikan ${ }^{14}$. Hal ini dikarenakan semakin kompleks kasus dan koordinasi, tentu saja akan

12 Artikel “Ayo Bersama-Sama Atasi Transnasional Crime," Jurnal Ibukita.Com, last modified 2016, accessed February 24, 2021, https://jurnalibukota.wordpress.com/2016/03/23/siti-nurbaya-ayo-bersama-sama-atasitransnational-crime/.

${ }^{13}$ Indriyane Vera Natalia and Maret Priyatna, "Optimization of the Multidoor Approach Implementation in Handling Criminal Case in The Environmental Field," Jurnal TALREV V, no. 1 (2020): 99-115.

${ }^{14}$ Murti, "Penguatan Kebijakan Penegakan Hukum Multidoor Sebagai Deterent Effect Untuk Menekan Laju Kasus Korupsi (Studi Kasus; Penerapan Pendekatan Multidoor Di Kementerian Lingkungan Hidup Dan Kehutanan).”Op.Cit., 
berbanding lurus dengan anggaran yang diperlukan ${ }^{15}$. Kebijakan akan hadirnya pendekatan multidoor, akan memberikan dampak yang sangat baik dalam upaya penegakan hukum baik secara administrasi maupun perdata. Namun, berbeda dengan pidana, bahwa tidak akan menimbulkan dampak lebih terhadap upaya penegakan hukum pidana secara represif, karena jelas bahwa secara asas legalitas dan asas lex specialis derogate legi generalis, bahwa masingmasing penegak hukum yang mempunyai tugas dan kewenangannya secara khusus yang diberikan Undang-Undang terkait beberapa perbuatan yang dilakukan oleh pelaku(tersangka/terdakwa), satu sama lain mempunyai kewenangannya.

Berbicara peraturan kebijakan, maka akan memiliki substansi dan kekuatan mengikat yang tidak berbeda dengan peraturan perundang-undangan, tetapi pola hukum atau tata hukum tidak mengategorikan peraturan kebijakan sebagai peraturan perundang-undangan. Jika dilihat dari format dan bentuknya kebijakan seringkali sama dengan peraturan perundangundangan, lengkap dengan pembukaan berupa konsiderans "menimbang", dasar hukum “mengingat", batang tubuh berupa pasal-pasal, bagian, bab serta penutup yang serupa dengan peraturan perundang-undangan ${ }^{16}$. Namun, secara praktek bahwa tak sedikit pengaturan kebijakan akan menimbulkan ketidakpastian hukum, terutama dalam perihal kekuatan mengikatnya. ${ }^{17}$ Atas dasar keadilan dan demi pembentukan penegakan hukum yang terintegrasi secara multidoor (integrated multidoor law enforcement) antar instansi dan penegakan hukum bersama secara multidoor (joint multidoor law enforcement) dalam operasi penyidikan terhadap pelaku atas beberapa perbuatannya tersebut, maka diperlukan kajian lebih serius untuk membahas dasar hukum dari suatu pendekatan multidoor system. tentunya bahwa strategi ini sangat layak untuk dipertahankan dan dikembangkan dalam tata aturan yang lebih jelas mengikat tidak berasal dari kebijakan yang hadir dari satu Undang-Undang, karena secara logika sederhananya bahwa suatu kebijakan yang menginstruksikan penegak hukum untuk bekerja sama melakukan proses penegakan hukum, terlebih pidana dalam proses penyidikan akan menjadi sulit untuk diterapkan secara praktiknya. Kesulitannya ialah terjadinya benturan dengan permasalahan yang umum ditemukan, yakni ego-sektoral dari

\footnotetext{
${ }^{15}$ Ibid.

16 Victor Imanuel Nalle, "Kedudukan Peraturan Kebijakan Dalam Undang-Undang Administrasi Pemerintahan,” Refleksi Hukum: Jurnal Ilmu Hukum 10, no. 1 (2016): 1.

${ }^{17}$ Ibid.
} 
masing-masing penegak hukum yang terlibat sesuai dengan Undang-Undang yang memberikan kewenangan.

Sejalan dengan pernyataan diatas, maka diperlukannya pembentukan hukum atau pembaharuan hukum terkait multidoor system yang menciptakan integrated multidoor law enforcement. Hal ini diperuntukkan agar penegakan hukum lebih baik dan berdayaguna dalam kepentingan lingkungan hidup dan nilai-nilai keadilan.”. Dalam upaya menjaga nilai-nilai keadilan tersebut, maka diperlukan penegakan hukum. Hal ini dikemukakan oleh Jimmly Asshiddiqie, bahwa terdapat empat fungsi penting yang memerlukan perhatian yang seksama yaitu $^{18}$;

a. Pembuatan hukum ('the legislation of law' atau 'law and rule making');

b. Sosialisasi, penyebarluasan dan bahkan pembudayaan hukum (socialization and promulgation of law);

c. Penegakan Hukum (the enforcement of law).

Begitu dengan kebijakan hukum nasional dalam bidang hukum lingkungan hidup yang menerapkan pendekatan multidoor system sebagai upaya penegakan hukum lingkungan hidup dan tindak pidana atau kejahatan lainnya. Hal ini akan menjadi menarik untuk ditinjau kembali akan strateginya, bahwa suatu kebijakan nasional yang dilakukan oleh pemerintah (eksekutif) untuk menggabungkan beberapa peraturan perundang-undangan yang ada patut untuk dikaji dan diteliti secara mendalam aturan perundang-undangan untuk memaksimalkan hukuman. ${ }^{19}$ Pendekatan multidoor system ini tentunya akan diimplementasikan secara konkret oleh penegak hukum yang ada. Secara umum bahwa Proses bekerjanya aparat penegak hukum itu, terdapat tiga elemen penting yang mempengaruhi, yaitu; (i) institusi penegak hukum beserta berbagai perangkat sarana dan prasarana pendukung dan mekanisme kerja kelembagaan (ii) budaya kerja yang terkait dengan aparat nya, termasuk mengenai kesejahteraan aparat nya, dan (iii) perangkat peraturan yang mendukung baik kinerja kelembagaan nya maupun yang mengatur materi hukum yang dijadikan standar kerja, baik hukum material-nya maupun hukum acaranya.

\footnotetext{
18 Jimly Asshiddiqie, "Penegakan Hukum," Writer (2007): 1-2.

19 Richaldo Y Hariadja, "Intensifikasi Pendekatan Multidoor," Media Indonesia, last modified 2016, accessed February 26, 2021, https://mediaindonesia.com/read/detail/31464-intensifkan-pendekatan-multidoor.
} 
Merujuk pada tiga elemen penting tersebut, perlu adanya tinjauan yang mendalam dan komprehensif atas keberlangsungan akan adanya pendekatan multidoor system, bahwa perlu adanya penelitian lebih lanjut terkait budaya kerja dari masing-masing penegak hukum yang terlibat dalam pendekatan multidoor system ini, bentuk kerjasama dan koordinasi antar institusi penegak hukum apa saja yang terlibat dalam pendekatan ini dan perangkat peraturan yang mengikat dan mendukung kinerja baik secara kelembagaan nya maupun mengatur tata cara upaya penegakan hukum yang ideal secara bersama-sama dilakukan sesuai dengan pendekatan multidoor system tersebut.

\section{Reorientasi atas permasalahan yang timbul dari Pengaturan Kebijakan Multidoor} system dalam Penegakan Hukum Tindak Pidana Lingkungan Hidup pada Sistem

\section{Peradilan Pidana Indonesia}

Multidoor system atau Multi-rezim hukum merupakan salah satu cara atau langkah aparatur penegakan hukum untuk mendorong supremasi hukum yang lebih baik dengan menjamin bahwa semua tindak pidana yang terjadi di wilayah Negara Kesatuan Republik Indonesia dapat ditangani dengan tepat dan proporsional. ${ }^{20}$ Dengan adanya Multidoor system, diharapkan adanya kolaborasi antar lembaga penegak hukum akan meningkatkan kapasitas penegakan hukum, baik kebutuhan untuk meningkatkan efektivitas penegakan hukum terkait kejahatan lingkungan hidup dan sumber daya alam. ${ }^{21}$

Pendekatan multidoor system ini merupakan bagian dari komitmen nya untuk melindungi sumber daya alam nasional, UNDP dan Program UN-REDD, dengan dukungan dari Norwegia, telah bekerja sama dengan Kementerian Lingkungan Hidup dan Kehutanan, Kepolisian Nasional, dan Kejaksaan Agung. ${ }^{22}$ Pendekatan baru yang baik dan efektif ini, untuk mengatasi kejahatan terkait lingkungan di kawasan hutan dan lahan gambut, termasuk kebakaran hutan “., New effective approach to tackle environment-related cries in forest areas

\footnotetext{
${ }^{20}$ Hamzah Kharisma and Syafruddin, "Pendekatan Multi Rezim (Multi Door System) Pada Tindak Pidana Perikanan," Borneo Law Review 3, no. 1 (2019): 53-72.

${ }^{21}$ Sekretariat Direktorat Jenderal Penegakan Hukum Lingkungan Hidup dan Kehutanan, Rencana Kerja 2019 Direktorat Jenderal Penegakan Hukum Lingkungan Hidup Dan Kehutanan Diterbitkan Oleh Sekretariat Direktorat Jenderal Penegakan Hukum Lingkungan Hidup Dan Kehutanan.

${ }^{22}$ Christophe Bahuet, "Multi-Door Approach' to Address Forest- Retalated Crimes in Indonesia," The Jakarta Post, last modified 2016, accessed February 23, 2021, https://www.thejakartapost.com/news/2016/03/21/multi-door-approach-address-forest-related-crimesindonesia.html.
} 
and peatlands, including forest fires.". ${ }^{23}$ Pendekatan ini disebut 'pendekatan multi (banyak)pintu', upaya untuk mencegah pelanggar melanggar hukum lingkungan Indonesia dan untuk memastikan bahwa akuntabilitas perusahaan, pemulihan kerugian negara dan pemulihan lingkungan dimasukkan ke dalam setiap investigasi untuk kejahatan terkait hutan. Hal ini sesuai dengan pernyataan "This approach is called the 'multi-door approach' and attempts to both prevent offenders from violating Indonesia environmental laws and to ensure that corporate accountability, recovery of state loses and restoration of the environment are incorporated into every investigation for forest-related crimes. ${ }^{24}$

Guna menjaga keseimbangan pembangunan dan daya dukung lingkungan hidup perlu dibangun sistem pengawasan pemanfaatan sumber daya alam. Kementerian Lingkungan Hidup dan Kehutanan telah memiliki sistem pengawasan pemanfaatan sumber daya alam yang salah satu instrumen nya adalah penegakan hukum, yaitu Direktorat Jenderal Penegakan Hukum Lingkungan Hidup dan Kehutanan (Ditjen Gakkum KLHK). Sedangkan peluangnya, untuk mengatasi kompleksitas kejahatan lingkungan hidup dan kehutanan dilaksanakan dengan adanya dasar hukum yang kuat atau konstitusi negara Republik Indonesia dan tujuh Undang-Undang tentang Konservasi, Kehutanan, Pengelolaan Lingkungan Hidup, sampah dan pencucian uang.

Penegakan hukum lingkungan hidup dan kehutanan ini juga terlaksana dengan adanya komitmen yang sungguh-sungguh dari pemimpin negara yang tercermin dalam Nawacita dan Rencana Pembangunan Jangka Menengah Nasional. Dukungan Masyarakat, kolaborasi dan koordinasi institusi penegakan hukum, keterbukaan informasi dan pemanfaatan teknologi semakin menunjang terciptanya sistem penegakan hukum lingkungan hidup dan kehutanan yang bertujuan mencapai pembangunan yang berwawasan lingkungan. ${ }^{25}$

Sebagaimana telah dipaparkan dan diketahui bahwa multidoor system merupakan suatu pendekatan untuk menggabungkan beberapa peraturan perundang-undangan. Hal ini perlu perhatian khusus, bahwa secara pengertian "pendekatan” yang berlandaskan pada Kamus Besar Bahasa Indonesia, memiliki arti dan makna ialah pada suatu cara, proses, atau hal

\footnotetext{
23 Ibid.

24 Ibid.

${ }^{25}$ Sekretariat Direktorat Jenderal Penegakan Hukum Lingkungan Hidup dan Kehutanan, Rencana Kerja 2019 Direktorat Jenderal Penegakan Hukum Lingkungan Hidup Dan Kehutanan Diterbitkan Oleh Sekretariat Direktorat Jenderal Penegakan Hukum Lingkungan Hidup Dan Kehutanan.
} 
(perbuatan, usaha) mendekati atau mendekatkan. Sehingga, apabila dihubungkan dengan multidoor system merupakan pemaknaan yang tepat dan ideal untuk dijadikan strategi upaya penegakan hukum terhadap kejahatan atau tindak pidana yang kompleks atau berbagai peraturan yang telah dilanggar.

Pendekatan multidoor system, akan mendorong para aparat penegak hukum untuk melakukan kerjasama dan bahkan dapat dijadikan dasar untu mengatasi ego-sektoral dari masing-masing penegak hukum yang terlibat dan berwenang sesuai dengan UndangUndangnya. Namun perlu diperhatikan sebagaimana gagasan diatas, bahwa perlu adanya peninjauan kembali terkait wawasan hadirnya multidoor system. Perlu diperhatikan tata hukum Indonesia (Peraturan perundang-Undangan) yang ada, bahwa sangat tidak mungkin suatu kebijakan dari satu peraturan perundang-undangan dapat menginstruksikan banyak atau beberapa penegak hukum dari masing-masing instansi yang diatur dari Undang-Undang yang berbeda. Sekalipun bahwa kebijakan multidoor system ini diadopsi dan dilaksanakan berdasarkan Undang-Undang Secara Khusus selain dengan Undang-Undang Pengelolaan Lingkungan Hidup dan Kehutanan, sebagaimana kebijakan pemerintah, hal ini tidaklah ideal.

Sudah saatnya untuk membentuk peraturan hukum yang ideal, karena lebih dari 5 (lima) tahun lamanya sejak yang direncanakan pada tahun 2012-2013, kebijakan Pendekatan multidoor system ini dilaksanakan. Bahkan jawaban atas beberapa kendala dalam penanganan Tindak Pidana Lingkungan Hidup dan Kehutanan dengan menggunakan multidoor, antara lain koordinasi antar instansi yang masih lemah, belum terdapat mekanisme maupun standar/pedoman tentang multidoor secara teknis, dan kurangnya kesadaran PPNS untuk menerapkan pendekatan multidoor ini merupakan bagian dari dasar diperlukannya pengaturan secara jelas, kuat dan mengikat akan hadirnya pendekatan multidoor system dalam Hukum Acara Pidana.

Hal ini guna sebagai penguatan dari penerapan perbarengan tindak pidana (Samenloop van Strafbare Feiten) hingga kedepannya hakim akan menerapkan stelsel pemidanaan bagi pelaku, yang mengatur tugas dan wewenang masing-masing-masing penegak hukum secara tingkatannya baik dari upaya awal penyidikan (secara khusus dalam Pendekatan multidoor system) hingga pelaksanaan putusan pengadilan. Penguatan yang dimaksud ialah agar tidak terjadinya ego-sektoral dari masing-masing penegak hukum yang berwenang untuk melakukan penegakan hukum (penyidikan) maka diperlukan aturan secara khusus yang 
mengatur untuk menggabungkan beberapa penegak hukum dari berbeda instansi dan aturan yang mengaturnya. Kitab Hukum Acara Pidana (KUHAP) hanya mengatur pada bagian koordinasi Penyidik PPNS terhadap Penyidik Kepolisian, tidak terhadap sesama penyidik PPNS. Bahkan secara khusus dari masing-masing Undang-Undang yang ada, terkait dengan tugas dan wewenang penyidik PPNS hanya mengatur koordinasi dengan Penyidik Polri tidak dengan sesama penyidik PPNS yang berbeda instansi, apabila pelaku melakukan beberapa perbuatan yang melanggar beberapa Undang-Undang.

Berbicara pendekatan, bahwa Criminal justice system atau sistem peradilan pidana diartikan sebagai pemakaian pendekatan dalam administrasi peradilan pidana ${ }^{26}$.Banyak definisi dan makna dari pada sistem peradilan pidana dari berbagai ahli, namun pada umumnya dapat sepakati bersama, bahwa sebagai suatu sistem peradilan pidana yang merupakan hasil interaksi antara peraturan perundang-undangan, praktek administrasi dan sikap tingkah laku sosial. Peryataan tersebut merupakan pendapat dari Remington dan Ohlin dalam bukunya Romli Atmasasmita, yang tentunya secara umum memiliki persamaan makna maksud yang sama baik dengan Hagan, Mardjono, Muladi, dan ahli lainya.

Pengertian sistem ini mengandung implikasi suatu proses interaksi secara rasional dan efisien untuk memberikan hasil tertentu. Sehingga, apabila dihubungkan dengan pemaknaan Multidoor system dan Criminal Justice System, tentunya memiliki persamaan makna namun berbeda dasar sumber praktiknya. Criminal Justice System ada pada tataran peradilan pidana sedangkan Pendekatan multidoor system berada pada kaitannya dengan hukum lingkungan yang ada di dalamnya terdapat pula bagian pidana.

Pendekatan normatif atau peraturan perundang undangan yang dimaksud ialah yang memandang keempat aparatur (Kepolisian, Kejaksaan, Pengadilan, dan Lembaga Pemasyarakatan) sebagai institusi pelaksana peraturan perundang-undangan yang berlaku sehingga keempat aparatur tersebut merupakan bagian yang tidak terpisahkan dari sistem penegakan hukum semata-mata. Sedangkan, Pendekatan manajemen atau administratif yang memandang keempat aparatur penegak hukum sebagai suatu organisasi manajemen yang memiliki mekanisme kerja, baik hubungan yang bersifat horisontal maupun yang bersifat vertikal sesuai dengan struktur organisasi yang berlaku dalam organisasi tersebut. Sistem yang

${ }^{26}$ Romli Atmasasmita, Sistem Peradilan Pidana Kontemporer (Jakarta: Kencana Prenadia Media Group, 2010), hal 2. 
digunakan adalah sistem administrasi. Serta, Pendekatan sosial yang memandang keempat aparatur penegak hukum merupakan bagian yang tidak terpisahkan dari suatu sistem sosial sehingga masyarakat secara keseluruhan ikut bertanggung jawab atas keberhasilan atau ketidakberhasilan dari keempat aparatur penegak hukum tersebut dalam melaksanakan tugasnya.

Mencoba untuk mengamati sub-sistem penyidikan yang terlibat dalam multidoor system ini akan beragam, sesuai dengan ditemukannya bukti akan terjadinya banyak atau beberapa tindak pidana, yang melibatkan banyak Penyidik PPNS yang ada turut untuk melakukan tugas pendidikannya. Hal diatas dapat terlihat mudah untuk dicerna, dikarenakan kajian atas pendekatannya berbentuk normatif yang ada, namun, apabila melihat dari segi manajemen atau administratif, maka hal ini akan menjadi sulit dikarenakan masing-masing penyidik PPNS yang ada memiliki mekanisme kerja yang berbeda-beda, bahkan secara struktural organisasi akan berbeda. Bahkan peraturan pelaksana yang ada pun berbeda. Hal ini perlu untuk dilakukan penelitian lebih lanjut terkait pendekatan ini, dikarenakan dalam tataran praktiknya masih sering terjadi ego-sektoral yang tidak melaksanakan penegakan hukum yang terintegrasi. Akan tetapi perlu catatan bahwa secara pendekatan normatif pun masih mempunyai permasalahan, yakni dengan batasan sumber dari hadirnya multidoor system ini dari suatu kebijakan maka akan sulit untuk menginstruksikan penegak hukum atau penyidik PPNS untuk melakukan penegakan hukum yang terintegrasi.

Selain diksi dari pendekatan, apabila dikaji dari etimologis, maka akan menarik membahas arti dan makna "sistem". Sama hal dengan pendekatan keduanya memiliki pengertian sistem baik Criminal Justice System dan multidoor system. Sistem mengandung arti terhimpun (antar) bagian atau komponen (sub-sistem) yang saling berhubungan secara beraturan dan merupakan suatu keseluruhan. Sedangkan" peradilan pidana" merupakan suatu mekanisme pemeriksaan perkara pidana yang bertujuan untuk memeriksa (menghukum atau membebaskan) seseorang dari suatu tuduhan pidana. Apabila dihubungkan dengan hukum, maka akan membentuk suatu sistem hukum. Menurut Lawrence Meir Friedman, secara umum bahwa sistem hukum itu harus memenuhi Struktur (Structure), Substansi (Subtance), dan Kultur Hukum (Legal Culture). Serta, ketiga unsur sistem hukum tersebut, seringkali dijadikan dasar untuk mengukur berhasil dan efektif atau tidaknya dari suatu penegakan 
hukum yang dilakukan. Bahkan terdapat tambahan unsur yang keempat yaitu dampak atau impact. $^{27}$

Pertama, Struktur merupakan bagian-bagian yang bergerak dalam suatu mekanisme. Misalnya; secara penegakan hukum pidana maka Pengadilan, Hakim, Panitera dan lainnya. Bahkan secara umum mengenai penegakan hukum lingkungan hidup dan lainnya, terdapat instrumen penegakan hukum baik secara administrasi, perdata dan pidana telah diatur cukup baik berdasarkan Undang-Undangnya. Serta, struktur, ini juga menunjukan fasilitas. Kedua, Substansi, terdiri dari hasil-hasil yang diterbitkan oleh sistem hukum aturan tertulis dan kaidah hukum tertulis. Ketiga, Kultur Hukum, berisikan sikap publik dan nilai-nilai. Komponen tersebut, menunjuk kepada apakah pengadilan telah didayagunakan dengan baik. Bahkan bagian kultur hukum, termasuk di dalamnya dengan budaya malu dan lain sebagainya.

Berdasarkan unsur sistem hukum yang dimaksud diatas, bahwa perlu akan adanya pembahasan berkala terkait akan adanya pendekatan multidoor system dalam tata hukum Indonesia. Secara khusus terkait dengan keberadaan pendekatan tersebut. Apakah pendekatan multidoor system merupakan bagian penting dari hukum yang hidup dan berkembang dalam masyarakat, ataukah hanya sebatas dari pengadopsian secara perbandingan hukum dengan negara lain, sebut saja Norwegia dan lain sebagainya untuk menerapkan multidoor system. Sehingga, dalam upaya penegakan hukum yang baik dan ideal perlu akan adanya perbaikan substansi hukum yang berlandaskan dari budaya hukum yang ada dari masing-masing penegak hukum yang berbeda instansi tersebut, bahkan tentunya akan menghasilkan struktur hukum yang baik atas kewenangan penegak hukum dari masing-masing instansi yang ada sesuai Undang-Undangnya. Serta, akan berdampak yang positif terhadap masyarakat untuk menjadi jawaban pemerintah yang telah berkomitmen untuk memberantas dan serius menangani kejahatan modus baru dalam lingkungan hidup.

Setelah berbicara sistem hukum secara umum, maka dalam tataran implementasi pendekatan multidoor system dalam upaya penegakan hukum yang menggabung beberapa peraturan. Maka sepatutnya secara khusus, instrumen penegakan hukum pidana akan

${ }^{27}$ Lihat Bagir Manan, Pengembangan Sistem Hukum Nasional Dalam Rangka Memantapkan Negara Kesatuan Republik Indonesia Sebagai Negara Hukum, Daftar "Course Material” Politik Hukum (Bandung: Universitas Padjadjaran, 2001), hal .1-4 
berbicara Sistem Peradilan Pidana. Barda Nawawi Arief, telah berpandangan bahwa sistem peradilan pidana dapat dilihat dari berbagai aspek, yaitu: ${ }^{28}$

a. Aspek/komponen substansi hukum, sistem peradilan pada hakikatnya merupakan suatu penegakan substansi hukum di bidang hukum pidana meliputi hukum pidana materiil, hukum pidana formil, dan hukum pelaksanaan pidana. Merupakan sistem peradilan atau penegakan hukum yang terpadu (integrated legal system" atau "integrated legal substance");

b. Aspek/komponen struktural hukum, sistem peradilan pada dasarnya merupakan sistem bekerjanya/berfungsinya badan-badan/lembaga/aparat penegak hukum dalam menjalankan fungsi dan kewenangannya masing-masing di bidang penegakan hukum. Secara struktural, sistem peradilan merupakan "sistem administrasi/penyelenggaraan" atau sistem fungsi operasional" dari berbagai struktur/profesi penegak hukum. (Integrated criminal justice system' atau 'the administration of criminal justice”);

c. Aspek/komponen budaya hukum, sistem peradilan, pada dasarnya merupakan perwujudan dari sistem "nilai-nilai budaya hukum, yang dapat mencakup filsafat hukum, asas-asas hukum, teori hukum, ilmu hukum dan kesadaran atau sikap perilaku hukum. Pada sudut budaya hukum, sistem peradilan, dapat dikatakan merupakan "integrated culture legal system".

Komponen Sistem peradilan pidana, yang diakui dalam praktek, dan diakui dalam kebijakan hukum pidana, yakni terdiri dari kepolisian, kejaksaan, pengadilan, pemasyarakatan, dan unsur yang juga sebagai daya dukung meliputi pembuat UndangUndang. ${ }^{29}$ Karenanya peran pembentuk Undang-Undang (Legislator) sangat menentukan dalam politik kriminal (criminal policy), yakni menentukan arah kebijakan hukum pidana dan hukum pelaksanaan pidana, yang hendak ditempuh sekaligus menjadi tujuan dari penegakan hukum. ${ }^{30}$ Demi menggapai tujuan penegakan hukum yang baik dan efektif maka diperlukan

\footnotetext{
${ }^{28}$ Barda Nawawi Arief, Reformasi Sistem Peradilan (Sistem Penegakan Hukum) Di Indonesia. Dalam Bunga Rampai Potret Penegakan Hukum Di Indonesia (Jakarta: Komisi Yudisial Republik Indonesia, 2009).

29 Syaiful Bakhri, Kebijakan Kriminal (Dalam Perspektif Pembaharuan Sistem Peradilan Pidana Indonesia) (Jakarta: Total Media, 2010).

${ }^{30}$ Ibid.
} 
pembaharuan dalam peraturan perundang-undangan, karena Peraturan perundang-undangan merupakan bagian atau subsistem dari sistem hukum. Negara Indonesia sebagai negara hukum, tentunya dalam upaya pembentukan peraturan perundang-undangan tidak dapat terlepas dari politik hukum. Oleh karena itu, apabila berbicara politik peraturan perundangundangan pada hakikatnya tidak dapat dipisahkan dari politik hukum. M. Mahfud MD mengemukakan pendapatnya, bahwa politik hukum meliputi: ${ }^{31}$

a. Pembangunan hukum yang berintikan pembuatan dan pembaharuan terhadap materi-materi hukum agar dapat sesuai dengan kebutuhan;

b. Pelaksanaan ketentuan hukum yang telah ada termasuk penegasan fungsi lembaga dan pembinaan para penegak hukum.

Lebih lanjut, bahwa M. Mahfud MD, berpandangan bahwa politik hukum adalah kebijakan resmi (legal policy) negara tentang hukum yang akan diberlakukan atau tidak akan diberlakukan (pembuat aturan baru atau mencabut aturan lama) untuk mencapai tujuan negara. ${ }^{32}$ Sehingga, apabila dihubungkan dengan pendekatan multidoor system yang merupakan suatu kebijakan bagian dari politik hukum pemerintah saat ini, maka perlu adanya pembaharuan hukum yang mengatur di dalamnya pelaksanaan fungsi atau tugas dari masingmasing penyidik PPNS yang secara bersama-sama di saat melakukan penyidikan atau penanganan perkara pada pelaku yang melanggar banyak peraturan. Batasan kewenangan dan penyidikan yang bersama tentunya perlu diatur dalam Undang-Undang, hal ini agar dapat menyikapi ego-sektoral yang ada antar penyidik PPNS yang selalu berdalil pada kewenangannya dengan menggunakan ke khususnya dari masing-masing Undang-Undang.

Peraturan kebijakan bukanlah peraturan perundang-undangan. Hal tersebut dikarenakan lembaga yang membentuk peraturan kebijakan tidak memiliki kewenangan pembuatan peraturan perundang-undangan (wetgevende bevoegdheid). Bentuk peraturan kebijakan tidak langsung mengikat secara hukum, tetapi mempunyai relevansi hukum. Pembentukan peraturan kebijakan (beleidsregel) didasarkan pada adanya beoordelingsruimte (ruang pertimbangan) agar mengambil tindakan hukum publik yang bersifat pengaturan yang

\footnotetext{
${ }^{31}$ M. Mahfud MD, Politik Hukum Di Indonesia, II. (Jakarta: LP3ES, 2001).

32 Sopiani Sopiani and Zainal Mubaraq, "Politik Hukum Pembentukan Peraturan Perundang-Undangan Pasca Perubahan Undang-Undang Nomor 12 Tahun 2011 Tentang Pembentukan Peraturan Perundang-Undangan," Jurnal Legislasi Indonesia Vol 17, (2) (2020): 146-153.
} 
diberikan pembentuk Undang-Undang kepada pejabat atau badan-badan pemerintah atas inisiatif guna menyelesaikan masalah penyelenggaraan pemerintahan atas inisiatif sendiri. Inisiatif ini berupa tindakan nyata yang positif guna menyelesaikan masalah-masalah penyelenggaraan pemerintah yang dihadapi pada saat tertentu uang memerlukan pengaturan. ${ }^{33}$ Selaras dengan hal diatas bahwa multidoor system merupakan inisiatif baik dari pemerintah untuk membangun koordinasi yang konsisten terhadap antar instansi penegak hukum yang terlibat sesuai dengan kewenangannya. Hal ini dilaksanakan karena cukup sering terjadinya tumpang tindih kewenangan penegak hukum dan bahkan kebijakan yang berpotensi menimbulkan kepentingan.

Beberapa instansi yang terkait dalam satu mata rantai kasus pelanggaran dan kejahatan lingkungan hidup dan kehutanan bahkan suap dan korupsi, sangat menentukan proses penegakan hukum, kurangnya koordinasi dengan berbagai instansi terkait akan menyulitkan penerapan kebijakan ini. Selain itu, kekurangannya penerapan pendekatan multidoor system, masih terdapat kendala dalam koordinasi yang tidak terfasilitasi dengan baik, kurang adanya sinergitas dan belum ada mekanisme secara jelas yang mengaturnya. Dalam hal ini perlu dibangun kesepahaman dan kesatuan semangat lintas instansi. ${ }^{34}$ Oleh karena itu, diperlukan pembahasan lebih lanjut terkait keberadaan pendekatan multidoor system, yang dilakukan secara umum oleh lebih banyak instansi yang ada dan terlibat, sesuai dengan modus kejahatan lingkungan saat ini.

\section{Penutup}

Pendekatan multidoor system merupakan suatu kebijakan pemerintah nasional untuk mengatasi kejahatan modus baru dalam lingkungan hidup. Kebijakan multidoor system tersebut, merupakan bagian dari politik hukum nasional yang dilakukan oleh pemerintah Negara Indonesia, dengan cara suatu pendekatan untuk menggabungkan beberapa peraturan perundang-undangan. Termasuk di dalamnya kewenangan banyak penegak hukum yang terlibat sesuai dengan Undang-Undang yang ada. Namun, untuk lebih lanjut perlu adanya

33 Ni Luh Gede Astariyani and Bagus Hermanto, "Paradigma Keilmuan Dalam Menyoal Eksistensi Peraturan Kebijakan Dan Peraturan Perundang-Undangan: Tafsir Putusan Mahkamah Agung," Jurnal Legislasi Indonesia 16 (4) (2019): 433-447.

${ }^{34}$ Murti, "Penguatan Kebijakan Penegakan Hukum Multidoor Sebagai Deterent Effect Untuk Menekan Laju Kasus Korupsi (Studi Kasus; Penerapan Pendekatan Multidoor Di Kementerian Lingkungan Hidup Dan Kehutanan)." 
peninjauan kembali akan hadirnya dan pelaksanaan kebijakan Pendekatan multidoor system, yang secara khusus pada bagian penerapan hukum pidana akan menimbulkan kesulitan dalam praktik penegakan hukum dan hubungan kinerja antar sub-sistem dalam sistem peradilan pidana secara khusus bagian penyidikan akan semakin rumit. Hal ini dikarenakan multidoor system merupakan suatu kebijakan yang tidak kuat dan mengikat sebagaimana UndangUndang, yang pada umumnya kebijakan ini hanya untuk menerapkan Undang-Undang yang ada. Bahkan secara implementasinya masih memerlukan pengaturan lebih jelas dan tegas mengenai kewenangan dari masing-masing instansi penegak hukum atas beberapa perbuatan pelaku (tersangka/terdakwa).

Berdasarkan pemaparan dan kesimpulan diatas, maka terdapat beberapa saran yaitu sebagai berikut:

1. Perlu adanya pembahasan (kajian) lebih lanjut terkait Politik Hukum Negara Indonesia, atas keberadaan/eksistensi pendekatan multidoor system dalam Tindak Pidana Lingkungan Hidup dan tindak pidana lainnya, baik secara unsur kelembagaan, organisasi. penegakan hukum, pelayanan dan pengelolaan lingkungan hidup, yang membentuk suatu pengaturan berupa Undang-Undang, untuk menjadi dasar hukum yang kuat dan mengikat terhadap instansi penegak hukum dari masing-masing instansi dan Undang-Undang yang mengaturnya sehingga dapat menjadi solusi yang terintegrasi untuk mengatasi ego sektoral yang ada.

2. Apabila kajiannya menghasilkan urgensi pembentukan dan pembaharuan hukum terkait hadirnya pendekatan multidoor system dalam tindak pidana lingkungan hidup dan tindak pidana lainnya, maka dapat menggunakan teknik omnibus law untuk merevisi atas Undang-Undang yang ada, terkait pengaturan secara menyeluruh dan komprehensif mengenai pelaksanaan pendekatan multidoor system dalam Hukum positif Indonesia. Sedangkan, apabila tidak menghasilkan kebutuhan atau urgensi nya atas pendekatan multidoor system, maka sebaiknya atau idealnya, bahwa kebijakan multidoor system tersebut ditiadakan dalam strategi upaya penegakan hukum lingkungan hidup dan lainnya di Indonesia. 


\section{Daftar Pustaka}

\section{Jurnal}

[1] Astariyani, Ni Luh Gede, and Bagus Hermanto. "Paradigma Keilmuan Dalam Menyoal Eksistensi Peraturan Kebijakan Dan Peraturan Perundang-Undangan: Tafsir Putusan Mahkamah Agung.” Jurnal Legislasi Indonesia 16 (4) (2019): 433-447.

[2] Anakotta, M. (2019). Kebijakan Sistem Penegakan Hukum Terhadap Penanggulangan Tindak Pidana Terorisme Melalui Pendekatan Integral. JURNAL BELO, 5(1), 46-66. DOI : https://doi.org/10.30598/belovol5issue1page46-66

[3] Kharisma, Hamzah, and Syafruddin. (2019), Pendekatan Multi Rezim (Multi Door System) Pada Tindak Pidana Perikanan, Borneo Law Review 3(1), 53-72.

[4] Nalle, Victor Imanuel, (2016), Kedudukan Peraturan Kebijakan Dalam Undang-Undang Administrasi Pemerintahan. Refleksi Hukum: Jurnal Ilmu Hukum 10(1) DOI: https://doi.org/10.24246/jrh.2016.v10.i1.p1-16

[5] Natalia, Indriyane Vera, and Maret Priyatna. (2020) "Optimization of the Multidoor Approach Implementation in Handling Criminal Case in The Environmental Field." Jurnal TALREV 5(1), 99-115.

[6] Sopiani, Sopiani, and Zainal Mubaraq, (2020), Politik Hukum Pembentukan Peraturan Perundang-Undangan Pasca Perubahan Undang-Undang Nomor 12 Tahun 2011 Tentang Pembentukan Peraturan Perundang-Undangan. Jurnal Legislasi Indonesia, 17 (2) 146153.

\section{Buku}

[7] Amirudin, and Zainal J. (2005) Pengantar Metode Penelitian Hukum. Jakarta: Raja Grafindo Persada.

[8] Anwar, Yesmil, and Adang. Sistem Peradilan Pidana, Konsep, Komponen Dan Pelaksanaannya Dalam Penegakan Hukum Di Indonesia. Widja Padjajaran, 2009.

[9] Arief, Barda Nawawi. (2009) Reformasi Sistem Peradilan (Sistem Penegakan Hukum) Di Indonesia. Dalam Bunga Rampai Potret Penegakan Hukum Di Indonesia. Jakarta: Komisi Yudisial Republik Indonesia.

[10] Asshiddiqie, Jimly. "Penegakan Hukum.” Writer (2007): 1-2.

[11] Atmasasmita, Romli. (2010) Sistem Peradilan Pidana Kontemporer. Jakarta: Kencana Prenadia Media Group. 
[12] Bakhri, Syaiful. (2010) Kebijakan Kriminal (Dalam Perspektif Pembaharuan Sistem Peradilan Pidana Indonesia). Jakarta: Total Media.

[13] Manan, Bagir. (2001) Pengembangan Sistem Hukum Nasional Dalam Rangka Memantapkan Negara Kesatuan Republik Indonesia Sebagai Negara Hukum, Daftar "Course Material” Politik Hukum. Bandung: Universitas Padjadjaran.

[14] MD, M. Mahfud. (2001) Politik Hukum Di Indonesia. II. Jakarta: LP3ES.

[15] Murti, Hani Afrinita. (2017) "Penguatan Kebijakan Penegakan Hukum Multidoor Sebagai Deterent Effect Untuk Menekan Laju Kasus Korupsi (Studi Kasus; Penerapan Pendekatan Multidoor Di Kementerian Lingkungan Hidup Dan Kehutanan)." In Reconstructing Public Administration Reform To Build World Class Government, 434445.

[16] Soekanto, Soerjono. (1986) Pengantar Penelitian Hukum. Jakarta: Penerbit Universitas Indonesia.

[17] Soekanto, Soerjono, and Sri Mamudji. (2001) Penelitian Hukum Normatif-Suatu Tinjauan Singkat. Jakarta: PT Raja Grafindo, Persada.

[18] Wiradipradja, E. Saefullah. (2015) Penuntun Praktis Metode Penelitian Hukum Dan Penulisan Karya Ilmiah Hukum. Bandung: Keni Media.

\section{Perundang-Undangan}

[11] Undang-Undang Dasar Negeri Republik Indonesia 1945.

[12] Undang-Undang Republik Indonesia No.8 Tahun 1981 Tentang Kitab Undang-Undang Hukum Acara Pidana (KUHAP).

[13] Undang-Undang Republik Indonesia No 32 Tahun 2009 tentang Perlindungan dan Pengelolaan Lingkungan Hidup.

[14] Undang-Undang Republik Indonesia Nomor 18 Tahun 2013 tentang Pencegahan dan Perusakan HutanUndang-Undang Republik Indonesia Nomor 39 Tahun 2014 tentang Perkebunan.

[15] Undang-Undang Republik Indonesia Nomor 37 Tahun 2014 tentang Konservasi Tanah dan Air.

[16] Undang-Undang Republik Indonesia Nomor 32 Tahun 2014 tentang Kelautan.

[17] Undang-Undang Republik Indonesia Nomor 18 Tahun 2008 tentang Sampah.

[18] Undang-Undang Republik Indonesia Nomor 18 Tahun 2008 tentang Sampah. 
[19] Undang-Undang Nomor 5 Tahun 1990 tentang Konservasi Sumber Daya Alam Hayati dan ekosistemnnya

[20] Undang-Undang Republik Indonesia Nomor 31 Tahun 2004 tentang Perikanan.

[21] Undang-Undang Republik Indonesia Nomor 41 Tahun 1999 tentang kehutanan

[22] Undang-Undang Republik Indonesia Nomor 26 Tahun 2007 tentang Penataan Ruang.

\section{Lain-Lain}

[23] Bahuet, Christophe. "“Multi-Door Approach' to Address Forest- Retalated Crimes in Indonesia." The Jakarta Post. Last modified 2016. Accessed February 23, 2021. https://www.thejakartapost.com/news/2016/03/21/multi-door-approach-addressforest-related-crimes-indonesia.html.

[24] Zamzam. "Kabandiklat Kejaksaan: Multidoor System Strategi Ampuh Berantas Karhutla Dan Pidana Minerba." Harian Terbit. Last modified 2019. Accessed February 26, 2021. https://harianterbit.com/read/110488/Kabandiklat-KejaksaanMultidoor-System-Strategi-Ampuh-Berantas-Karhutla-dan-Pidana-Minerba.

[25] “Ayo Bersama-Sama Atasi Transnasional Crime.” Jurnal Ibukita.com. https://jurnalibukota.wordpress.com/2016/03/23/siti-nurbaya-ayo-bersama-sama-atasitransnational-crime/.

[26] Sekretariat Direktorat Jenderal Penegakan Hukum Lingkungan Hidup dan Kehutanan. Rencana Kerja 2019 Direktorat Jenderal Penegakan Hukum Lingkungan Hidup Dan Kehutanan Diterbitkan Oleh Sekretariat Direktorat Jenderal Penegakan Hukum Lingkungan Hidup Dan Kehutanan. Jakarta, 2019. http://gakkum.menlhk.go.id/assets/infopublik/RENJA_GAKKUM_2019_4PRINT_A5 21.pdf.

[27] Barus, Kormen. "Penegakan Hukum Lingkungan Di Indonesia Masih Lemah." Industry.co.dd. Last modified 2019. Accessed February 24, 2021. https://www.industry.co.id/read/54751/penegakkan-hukum-lingkungan-di-indonesiamasih-lemah.

[28] Hariadja, Richaldo Y. "Intensifikasi Pendekatan Multidoor." Media Indonesia. Last modified 2016. Accessed February 26, 2021. https://mediaindonesia.com/read/detail/31464-intensifkan-pendekatan-multidoor. 